\title{
HAK KEKAYAAN INTELEKTUAL BAGI PEMEGANG HAK MEREK SUATU KARYA INTELEKTUAL
}

\author{
DIAN NOVITA \\ Fakultas Hukum, Universitas Wiraraja Sumenep \\ dianovita79@yahoo.co.id
}

\begin{abstract}
ABSTRAK
Merek merupakan suatu identitas dalam suatu produk baik berupa barang ataupun jasa. Adapun perlindungan hak terhadap suatu merek yaitu dengan adanya hukum perlindungan mengenai perlindungan merek bagi pemegang hak kepemilikan merek itu sendiri yang merupakan suatu identitas dalam suatu perusahaan. Diadakannya hukum tentang perlindungan merek itu sendiri untuk mencegah suatu keplagiatan mengenai identitas dikarenakan persaingan semakin ketat.
\end{abstract}

Kata kunci: Merek, Perlindungan bagi para pemegang hak.

\section{A. PENDAHULUAN}

Merek adalah sesuatu (gambar atau nama) yang dapat digunakan untuk mengidentifikasi suatu produk barang atau jasa yang ada di dalam pasaran.

Merek berfungsi sebagai tanda pengenal untuk membedakan hasil produksi yang dihasilkan seseorang atau beberapa orang secara bersama-sama atau badan hukum dengan produksi orang lain atau badan hukum lainnya sebagai alat promosi sehingga dalam mempromosikan hasil produksinya cukup dengan menyebut mereknya sebagai jaminan atas mutu barangnya menunjukkan asal barang atau jasa yang dihasilkan.

Objek atas merek adalah karya-karya seseorang yang berupa tanda, baik tulisan, gambar, kombinasi tulisan dan gambar yang diciptakan dengan tujuan untuk membedakan barang yang satu dengan yang lain tetapi yang sejenis.Setiapmerek menampilkan wujud reputasi yang bernilai moral, material, dan komersial.merek mempunyai posisi penting bagi berkembangnya usaha atau bisnis para pedagang atau pengusaha yang terbaik bagi konsumen.

Undang-undang Nomor 21 Tahun 1961 tentang Merek tersebut diganti dengan Undang-undang Nomor 19 Tahun 1992 tentang Merek sebagaimana telah diubah dengan Undang-undang Nomor 14 Tahun 1997 tentang Perubahan atas Undang-undang Nomor 19 Tahun 1992 tentang Merek.

Dalam konsiderans UUM 1992 itu dapat di lihat lagi berbagai alasan tentang pencabutan Undang-Undang Merek Tahun 1992,yaitu:

1. Merek sebagai salah satu wujud karya intelektual memiliki peranan pentingbagi pelancaran dan peningkatan perdagangan barang atau jasa.

2. Undang-Undang Merek Nomor 21 Tahun 1961 dinilai sudah tidak sesuai lagi dengan perkembangan keadaan dan kebutuhan.

Hukum merek berfungsi melindungi pemilik merektersebut dari pihak lain yang 
hendak mengambil keuntungan dengan cara tidakjujur. Saat ini Indonesia telah mempunyai Undang-undang Merek terbaru yaitu Undang-undang Nomor 15 Tahun 2001 yang diundangkan pada tanggal 1 Agustus 2001 seiring dengan telah diratifikasinya Konvensi Pembentukan World Trade Organization (WTO). Undang-undang ini menggantikan Undang-undang Nomor 19 Tahun 1992 tentang Merek sebagaimana telah diubah dengan Undang undang Nomor 14 Tahun 1997 tentang Perubahan atas Undangundang Nomor 19 Tahun 1992 tentang Merek.

Dalam konteks negara Indonesia, perlindungan hukum di bidang-bidang HAKI yang telah di atur dalam hukum Indonesia meliputi:

Rahasia Dagang ( Undang-undang Nomor 30 Tahun 2000, Desain Industri (Undang-undang Nomor 31 Tahun 2000), Hak Paten (Undang-undang Nomor 14 Tahun 2001), Hak Merek ( Undang-undang Nomor 15 Tahun 2001), Hak Cipta (Undang-undang Nomor 19 Tahun 2002), (Undang-undang HAKI, Tahun 2004.Dengan merek, produk barang atau jasa sejenis dapat dibedakan asal muasalnya, kualitasnya, serta keterjaminan bahwa produk itu original.Hal ini tertuang dalam konsiderans Undang-undang Nomor 15 Tahun 2001 tentang Merek bagian menimbang butir a yang berbunyi"bahwa di dalam era perdagangan global, sejalan dengan konvensikonvensi internasional yang telah diratifikasi Indonesia, peranan Merek menjadi sangat penting, terutama dalam menjaga persaingan usaha yang sehat,"

Undang-undang Nomor 15 Tahun 2001 tentang Merek mendefinisikan merek secara lebih detail yaitu yang berbunyi sebagai berikut:

1. "Merek adalah tanda yang berupa gambar, nama, kata, huruf, angkaangka, susunan warna, atau kombinasi dari unsur-unsur tersebut yang memiliki daya pembeda dan digunakan dalam kegiatan perdagangan barang atau jasa.".maka penulisan ini memfokuskan pada pembahasan tentang "perlindungan merek bagi pemegang hak merek ditinjau dari undang-undang nomor 15 tahun 2001 tentang merek."

\section{B. PEMBAHASAN}

Perlindungan Merek adalah salah satu bentuk kepastian hukum yang dibutuhkan investor, baik dalam maupun luar negeri.Dalam penjelasan Undang-Undang Nomor 15 Tahun 2001 tentang Merek, di jelaskan bahwa Selain harus memenuhi ketentuan sebagaimana dimaksud dalam bagian pertama bab ini,permohonan dengan menggunakan Hak Prioritas wajib dilengkapi dengan bukti dengan penerimaan permohonan pendaftaran merek yang pertama kali yang menimbulkan hak prioritas tersebut.

1. Bukti Hak Prioritas sebagaimana dimaksud pada ayat (1) diterjemahkan dalam bahasa indonesia.

2. Dalam hal ketentuan sebagaimana dimaksud pada ayat (1) dan ayat (2) tidak 
dipenuhi dalam waktu paling lama 3(tiga) bulan setelah berakhirnya hak mengajukan permohonan dengan menggunakan Hak Prioritas sebagaimana dimaksud dalam Pasal 11, permohonan tersebut tetap diproses, namun tanpa menggunakan Hak Prioritas.

Dalam hal ketentuan sebagaimana dimaksud pada ayat (1) dan ayat (2) tidak dipenuhi dalam waktu paling lama 3(tiga) bulan setelah berakhirnya hak mengajukan permohonan dengan menggunakan Hak Prioritas sebagaimana dimaksud dalam Pasal 11. agar merek tersebut bisa memperoleh perlindungan hukum harus memenuhi persyaratan-persyaratan yang diatur dalam Undang-undang Merek dan peraturanperaturan lain yang mengatur tentang merek.Hukum merek Indonesia menganut sistem "first to file", sehingga yang mendaftarkan pertama kali adalah yang berhak atas kepemilikan suatu merek. Agar merek-merek tersebut dapat dilindungi hukum, khususnya hukum merek di Indonesia, maka merek tersebut harus didaftarkan ke Departemen Kehakiman dan Hak Asasi Manusia - Direktorat Jenderal Hak Kekayaan Intelektual sehingga terdaftar dalam Daftar Umum Merek dan pemilik merek yang sebenarnya akan mendapat sertifikat merek sebagai tanda bukti hak/kepemilikan atas merek dagang produk.Sertifikat merek merupakan tanda bukti bahwa merek tersebut telah didaftarkan dalam Daftar Umum Merek.Undang-undang Nomor 15 Tahun 2001 tentang Merek memberikan hak ekslusif kepada pemiliknya.Hak ekslusif ini memberikan jaminan perlindungan hukum atas merek yang mereka gunakan. Hak ekslusif ini melarang produsen lain menggunakan merek dengan tulisan ataupun gambar yang sama pada kemasannya.

\section{Berdasarkan ketentuan dalam UU} No.15 Tahun 2001 tentang Merek, maka upaya penyelesaian sengketa di bidang merek dapat ditempuh melalui penyelesaian sengketa secara litigasi, alternatif penyelesaian sengketa ataupun arbitrase.

1. Litigasi

Litigasi merupakan salah satu upaya penyelesaian sengketa melalui lembaga pengadilan.Dari Undang-Undang Nomor 15 tahun 2001 tentang merek dapat diketahui ada jenis bentuk tuntutan gugatan atas pelanggaran merek terdaftar yang berbunyi, yaitu :41 gugatan ganti rugi atau penghentian penggunaan merek yang dilanggarnya. Ganti rugi disini dapat berupa ganti rugi materiil dan ganti rugi immateriil.Ganti rugi materiil berupa kerugian yang nyata dan dapat dinilai dengan uang.Sedangkan ganti rugi immateriil berupa tuntutan ganti rugi yang disebabkan oleh penggunaan merek dengan tanpa hak, sehingga pihak yang berhak menderita kerugian secara moral.

2. Non Litigasi

Sama halnya dengan penyelesaian sengketa paten, penyelesaian sengketa atas hak merek juga dapat dilakukan di 
luar pengadilan, baik menggunakan arbitrase atau alternative penyelesaian sengketa. Dalam Pasal 84 UndangUndang Nomor 15 Tahun 2001 tentang Merek dinyatakan bahwa selain penyelesaian gugatan melalui Pengadilan Niaga, para pihak dapat menyelesaikan sengketa melalui Arbitrase atau Alternatif Penyelesaian Sengketa.

a. Alternatif Penyelesaian Sengketa

Alternatif penyelesaian Sengketa adalah lembaga penyelesaian sengketa atau beda pendapat melalui prosedur yang disepakati para pihak yakni penyelesaian pengadilan dengan cara konsultasi, negosiasi, mediasi, konsiliasi, atau penilaian ahli.

b. Arbitrase

Menurut UU Nomor 30 Tahun 1999 tentang Arbitrase dan Alternatif Penyelesaian Sengketa, disebutkan bahwa :"Arbitrase adalah cara penyelesaian sengketa perdata diluar peradilan umum yang didasarkan pada perjanjian arbitrase secara tertulis oleh para pihak yang bersengketa" (Pasal.1 ayat (1)).

\section{Dalam Pasal.5 ayat}

ditentukan bahwa sengketa yang dapat diselesaikan melalui arbitrase hanya sengketa di bidang perdagangan dan mengenai hak menurut hukum dan peraturan perundang-undangan dikuasai sepenuhnya oleh pihak yang bersengketa.
Perjanjian arbitrase adalah suatu kesepakatan berupa klausul arbitrase yang tercantum dalam perjanjian tertulis yang dibuat para pihak sebelum timbul sengketa (Pactumdecompromittendo ) atau suatu perjanjian arbitrase tersendiri yang dibuat para pihak setelah timbul sengketa (Actecompromise).

\section{PENUTUP}

Didalam perlindungan merek merupakan upaya yang dapat menjamin adanya kepastian hukum, sehingga dapat memberikan perlindungan hukum yang bersangkutan atau yang melakukan tindakan hukum.

Pelaksanaan perlindungan hukum merek berdasarkan Undang-undang Nomor 15 Tahun 2001 tentang Merek, khususnya Pasal 3, yaitu mengenai pemberian hak eksklusif oleh negara kepada pemilik merek yang terdaftar dalam Daftar Umum Merek terhadap produk makanan belum dapat terlaksana dengan efektif.

Bagi mereka yang sudah memiliki sertifikat merek mengatakan bahwa mereka merasa lebih tenang dalam menjalankan usahanya ke depan. Selain itu, dengan adanya sertifikat merek, mereka merasa lebih mudah membuktikan hak atas kepemilikan merek yang mereka gunakan, sehingga dalam usahanya tidak lagi mencemaskan apabila suatu ketika ada yang menggugat merek yang mereka gunakan. Justru bagi mereka, sertifikat merek yang dimiliki bisa dijadikan alat untuk menggugat pihak lain yang dengan 
tanpa izin memproduksi dan menjual dengan merek yang sama sehingga merugikan konsumen yang sudah menjadi langganan. Sertifikat merek merupakan tanda bukti bahwa merek tersebut telah didaftarkan dalam Daftar Umum Merek.

Undang-undang Nomor 15 Tahun 2001 tentang Merek memberikan hak ekslusif kepada pemiliknya.Hak ekslusif ini memberikan jaminan perlindungan hukum atas merek yang mereka gunakan. Hak ekslusif ini melarang produsen lain menggunakan merek dengan tulisan ataupun gambar yang sama pada kemasannya. Akan tetapi hak tersebut tidak diberikan kepada para produsen yang belum memiliki sertifikat merek. Dalam kelanjutan usahanya, merek yang mereka gunakan bisa digunakan oleh orang lain.

Undang-undang Nomor 15 Tahun 2001 tentang Merek tidak memberikan perlindungan hukum bagi merek yang belum terdaftar dalam Daftar Umum Merek. Sehingga, produsen yang belum mendaftarkan mereknya tidak bias melakukan tindakan hukum atau gugatan kepada pihak ketiga yang memakai merek mereka tanpa izin.

Di dalam penyelesaian sengketa UndangUndang Nomor 15 Tahun 2001 Tentang Merek telah menyediakan 2 (dua) sarana hukum, yang dapat dipergunakan sekaligus untuk menindak pelaku pelanggaran terhadap hak merek, yakni sarana hukum Pidana dan hukum Perdata. Selaian adanya pidana dan perdata juga penyelesaian dibidang hak merek dapat di lakukan diluar pengadilan melalui arbitrase atau altermative penyelesaian sengketa.

Terhadap pelanggaran hak merek si pelanggaran selain dikenakan sanksi pidana juga secara keperdataannyadapat dituntut oleh pemilik hak merek dan/atau pemegang hak merekyang haknya di langgar. Mereka dapat mengajukan gugatan untuk menuntut ganti rugi kepada pihak yang dianggap melanggar haknya, sehingga hak untuk mengajukan gugatan perdata sama sekali tidak mengurangi hak Negara sehingga untuk melakukan upaya penuntutan pidana atas pelanggaran Merek tersebut.

\section{DAFTAR PUSTAKA}

Andrian Suteti, 2009, Hak Atas Kekayaan Intelektual, Jakarta: PT Sinar Grafika

Budi Agus Riswanto dan M. Syamsudin, 2004, Hak Kekayaan Intelektual dan Budaya Hukum, Jakarta: PT Raja Grafindo Persada.

Undang-undang Nomor 30 Tahun 2000 Tentang Rahasia Dagang, 2003, Sinar Grafika, Jakarta

Undang-undang Nomor 31 Tahun 2000 Tentang Desain Industri, 2003, Sinar Grafika, Jakarta

Undang-undang Nomor 14 Tahun 2001 Tentang Hak Paten, 2003, Sinar Grafika, Jakarta.

Undang-undang Nomor 15 Tahun 2001 Tentang Merek, 2003, Sinar Grafika, Jakarta. 


\section{FAKULTAS HUKUM UNIVERSITAS WIRARAJA SUMENEP - MADURA}

Undang-undang Nomor 19 Tahun 2002

Tentang Hak Cipta, 2004, Citra Internet, 14 November 2020, WWW:

Aditya Bakti, Jakarta.

http://wikipediaindonesia.com.

Internet, $10 \quad$ November 2020,

Http://Www.dgip.go.id 